\title{
أهمية التجربة في الطب عند فلاسفة الاسلام
}

أ.د. مجيد مخلف طراد

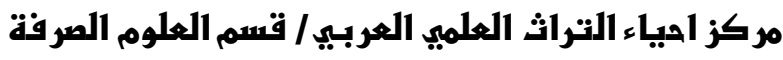

هلنمص البمث

التجربة احدى اهم مرتكز ات الطب عند فلاسفة الاسـلام ووصفوها بأنها علم لـه اصول وفروع و لا بد لاي طبيب ان يحكم اصولها

ويعرف فرو عها ولهذا لم يستغنى الطب عنها في كل مر احل التاريخيـة بداها بشكل بسيط في مر احلـة الاولى خاصـة في الحضـار ات الانسـانية

القديمة ثم تطور استخدامها يتطور الانسان و الته و ادو اته الطبية بلغت ذروة هذا التطور في التراث الفلسفي الاسلامي على يد اشهر و وامهر طبيينين هما ابي بكر الر ازي و ابن سينا فكانت عند الاول تجربة موجهة وليس اتفقية لها ضـو ابط واصـول دقيقة جداً حتى ان مفهومها اقترب كثير اً من الفهم الحديث لها، والثاني وضعها لها شروط عدة نجد فيها اصول المنهج البحث العلمي التجريبي الحديث في مجال الطب و العلوم الاخرى.

لقد اكد الفيلسوفان على اهمية التجارب في مجال الطب ودور ها الاساسي في الوصـول الى حقائق الاشياء عندما عدوها الفاصل او الحكم الذي ينبغي العودة اليه في الميز بين الخطأ والصو اب فكثير من خواص الاشياء وجزيئاتها وتفيلاتها لا بمكن النثبت من صحتها ولا لا يمكن

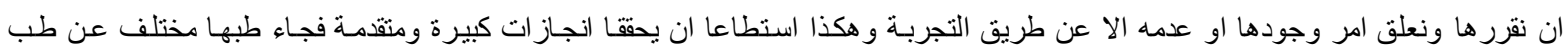
فلاسفة اليونان الذي كان في اغلب جو انبه طباً نظرياً لا تطبيقياً .

The importance of experiment of medicine in Islamic philosophy

Abstract :-

Experiment is one of the important basis medicine according to Islamic philosophy , contained basics and branches, in which every physicion must know them, and that had contained in every historical stage, medicine began simplicity in ancient humanity civilizaon which had developed the uses of it gradually by progressing of human and his machine , physicions (Al- Razi and Avi - cena) according to Al-Razi opinion, medicin experiment basics until they had arrived to its under standing of moder, wheras according to Ave-cena opinion, it considered as an experiment with conditions contained the origions of program pf scientific experminal modern research in space of medicin sciences The two philosophers would emphasize the importance of expermintes of medicine and its basic role to arrive to realistic of things as they had considered it as low to be are ferrece to be back to it .

In order to differenciate between right and wrong, The features of any things or particles could not be developed without experiments, there for, the scientists tried to achieve more accompli shrments to prominence medicine to be different from the one of Greece philosophy which was neither theortical hor applicable

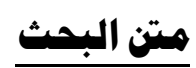

لا تختلف اهميـة التجربـة في الطب عن اهميتهـا في العلوم الاخرى فهي واحدة من اهم عناصر البحث العلمي

عمومـاً ، وركن اسـاسـي مـن اركـان الممارسـة الطبيـة على وجـه الخصـوص ، ولهذا جـاء تركيز فلاسفة الاسـلام عليهـا و اعتمدها في ابحاثها ودر استها الطبية . حتى اصبحت التجربيـة الصفة المميزة لمنهجهم البحثي في هذا المجال ، فلعبـ دور اً كبير اً في النتـائج التي توصـلوا اليها جـراء اعطائهـا الاولويـة في هذه الابحـاث و الدر اسـات ممـا جعل جهدهم الطبي يختلف عن ما كان سائداً عند اليونان التي كانت ابحاثهم الطبية في اغلب جوانبها نظرية لا تطبيقية.

وقبل البدء ببيان الهية التجربة في الطب عند فلاسفة الاسـلام لابد لنا من استعر اض تاريخي بسبط لدورها في

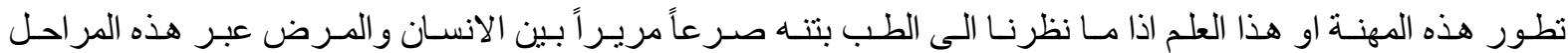


تعد حضـارة و ادي الر افدين و الحضـارة المصـرية همـا اقدم الحضـار ات الانسـانية وقد تز امن ظهور هـا الى حد

كبير ، و الدليل نلك التو اصل بينها في المجالات العلمية والثقافية كافه ، و وعلى الرغم من ان بدايـة الطب القديم في حضـارة

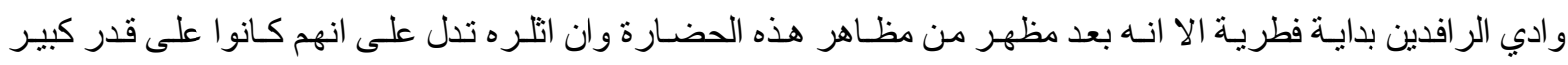

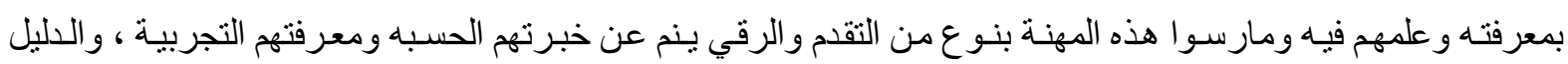

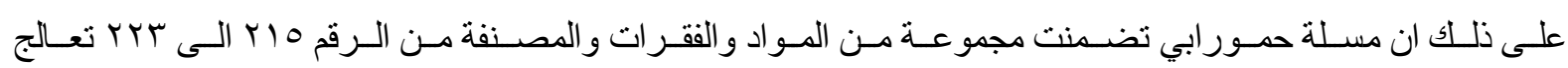
موضوعات الاذى المادي والجسدي .

و العقوبات المترنبة على الحساق الاذى بـالمو اطنين من قبل بعض اصحاب المهن عند مز اولتهم لاعمالهم، وتأتي

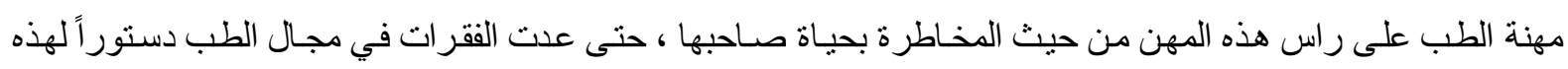

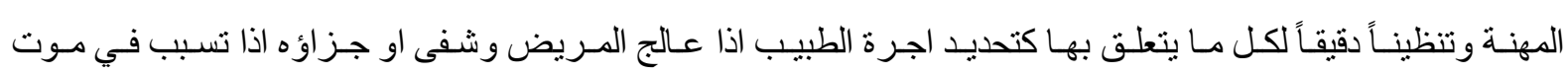

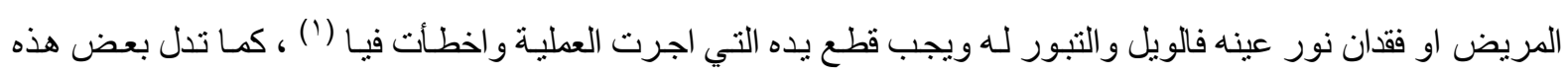

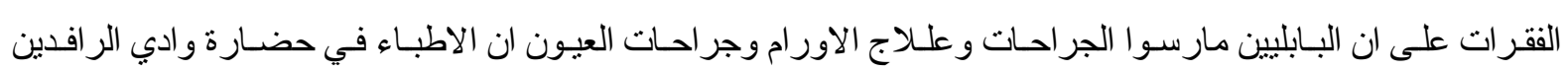

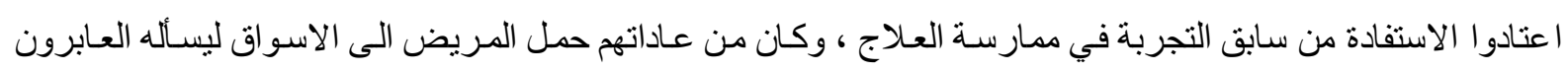

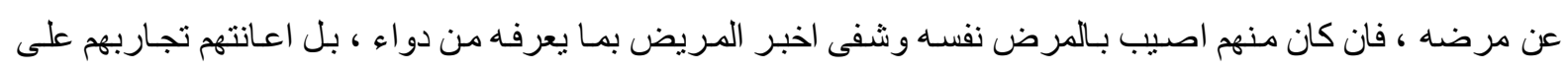

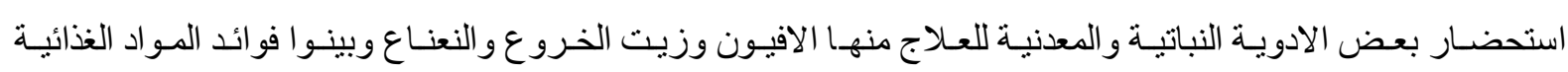

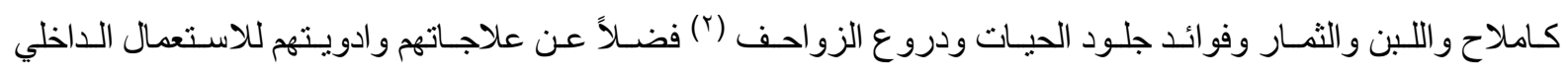

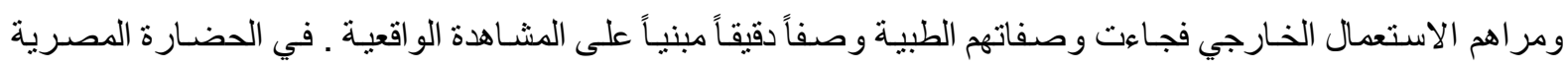

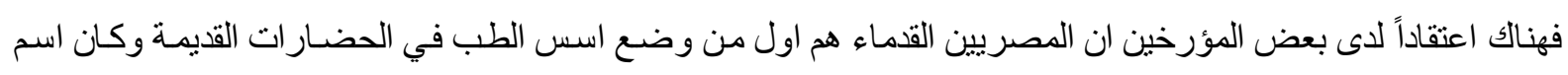

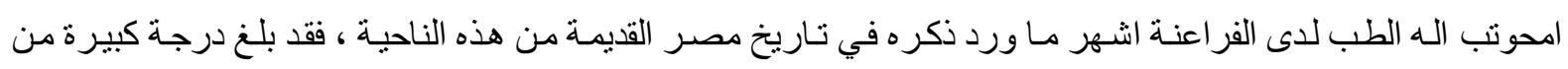

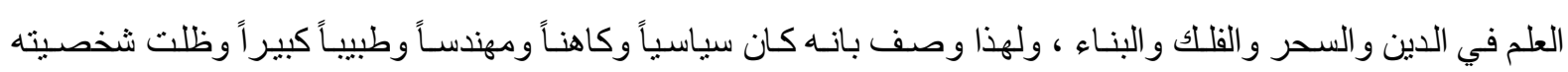

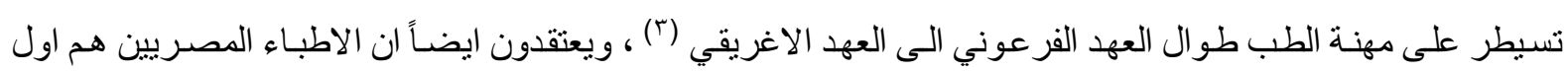
من مـارس التجربـة بابسط صـور ها في هذا المجال عندما قاتهم خبرتهم الحسية الى معرفة بعض الامـر اض واستعمال

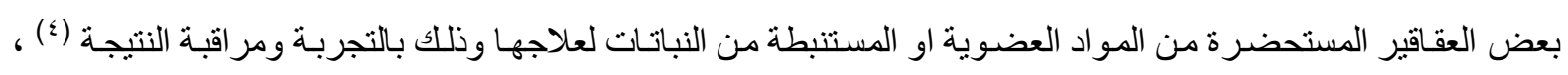

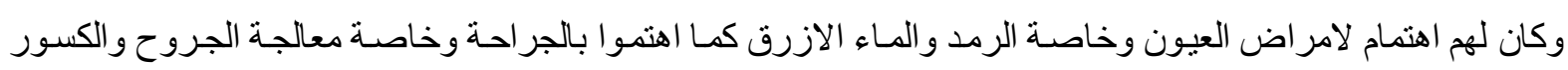

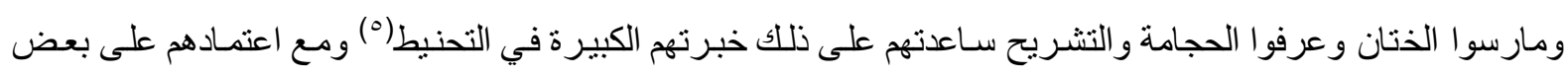

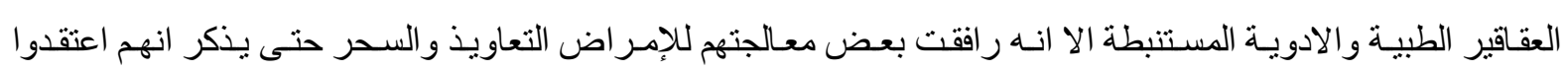

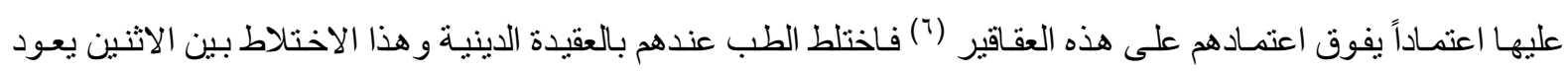

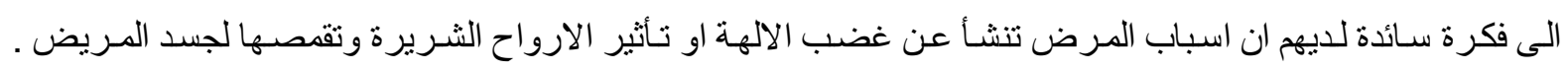

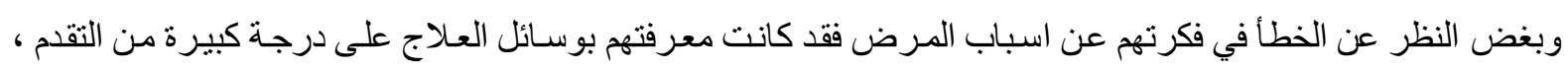

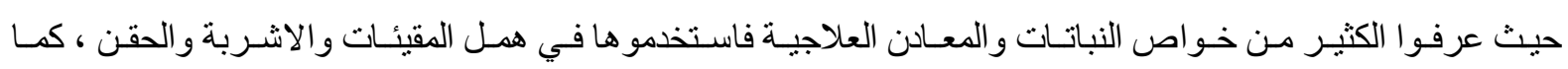
استخموا المر اهم و الغرغرات واستنشـاق الابخرة ، وفي مجـال الجر احـة كـان لهم شـان كبير من ذلك خبرتهم في عـلاج خلع المفاصل ووكف النزيف و التضميد وفي الصحة العامـة والوقايـة كانوا يحرصون على النظافـة ويعتنون بالاغتسـال

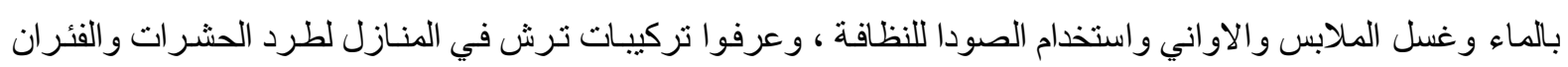
و الثعابين. 
امـا عند اليونـان فـاول مـن عرف الطب عن طريق التجربـة هو اسقلبيوس وهـو ايضـاً اول طبيب ذكر عنــ

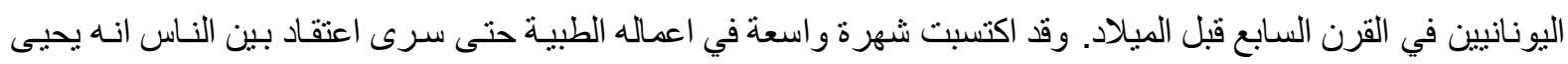

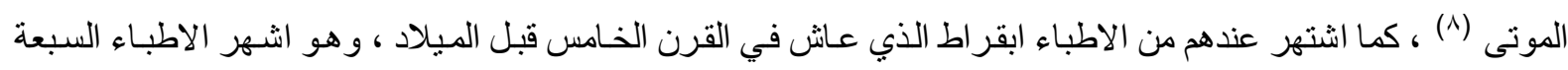

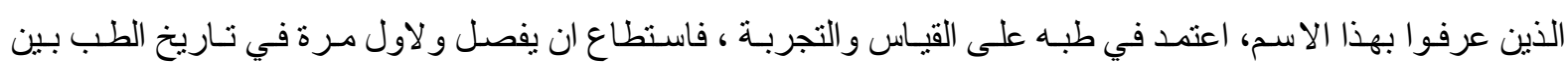

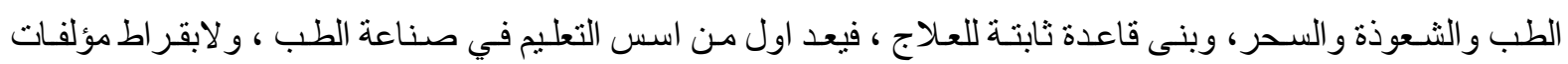

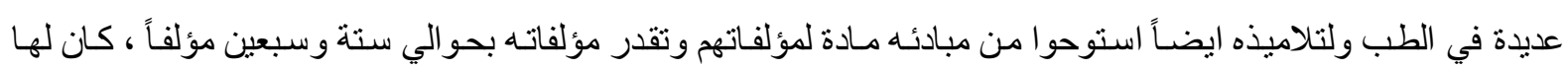
فيما بعد اثراً كبير أ في مجال الطب خاصـة عند اطباء العرب نرجمت معظمها اليهم عن طريق اللغة السريانية (9). كمـا

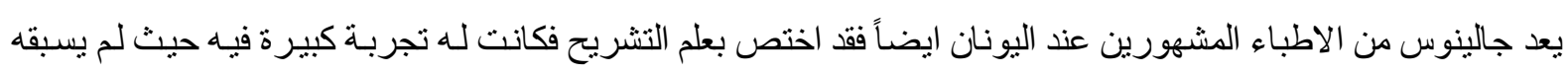

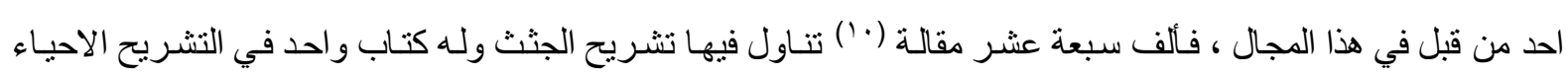

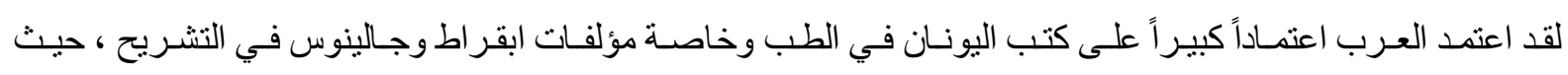

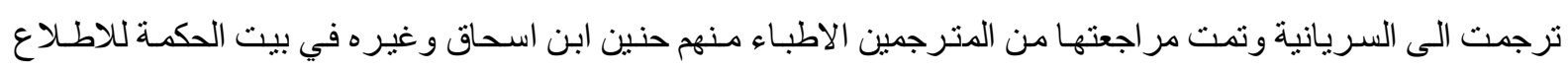

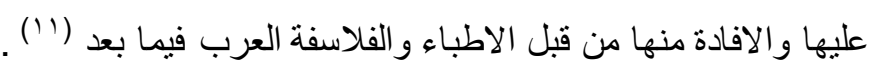

بعد ان ذكرنـا بسطور مصسادر الطب في الحضـار ات القديمـة ـ سنستعرض الان مصسادره في عصـور الدولــة

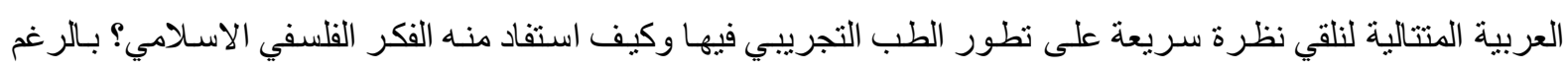
من تأكيد اغلب المصسادر التاريخية على ارتبـاط الطب العربي بالطب اليونساني في الحضـارة العربية الاسلامية ارتباطس

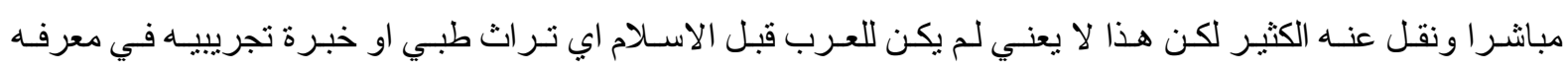

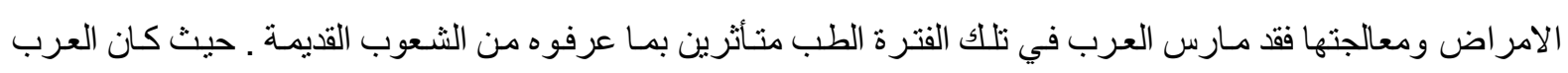

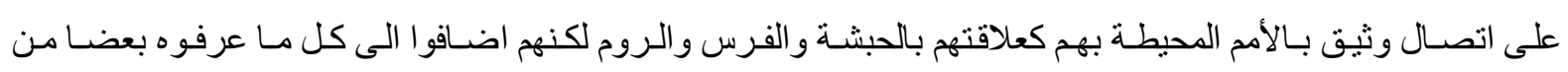

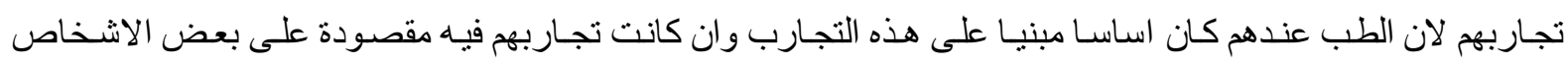

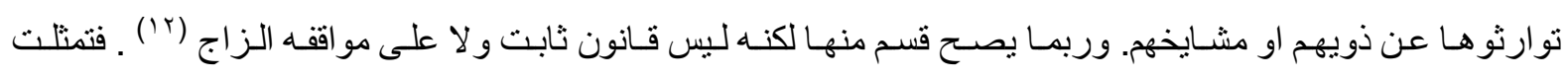

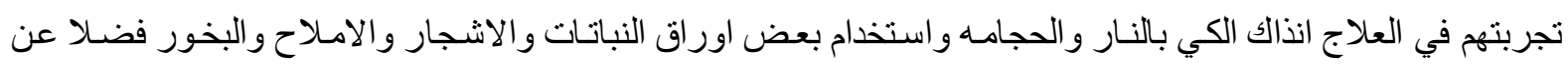

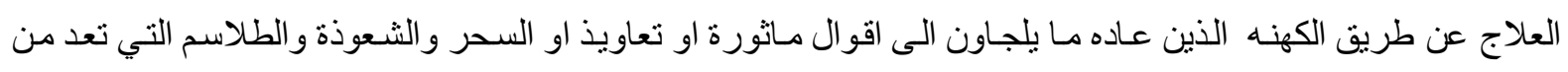

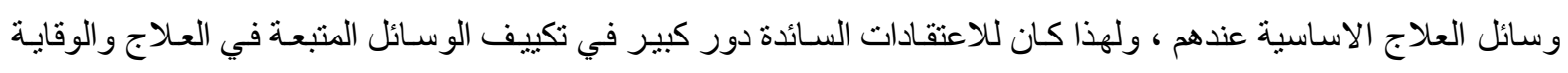

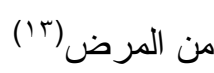

لقد اشـارت بعض المصـادر التاريخية الى وجود معـارف اصيلة في الطب العربي قبل الاسـلام من بينها عمليه النقب اي نقب بلورة العين او رفعها كليا في حالة العهى بمرض المـاء الابيض (الكاتار اكب) و المبدأ في هذه العمليه هو

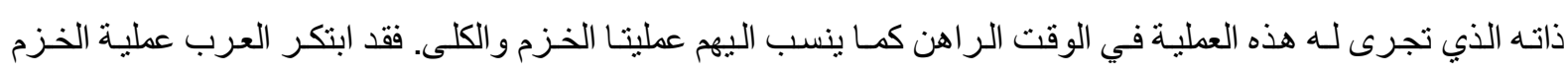

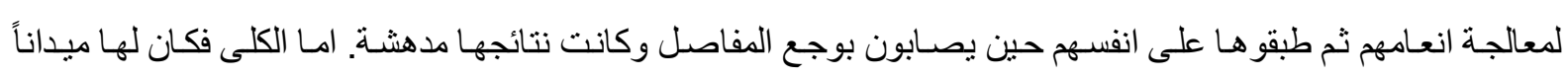

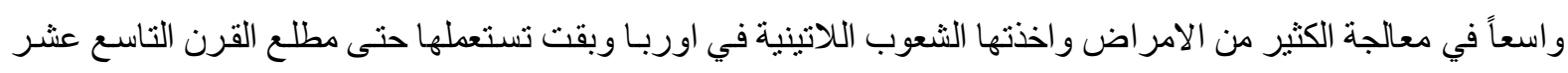

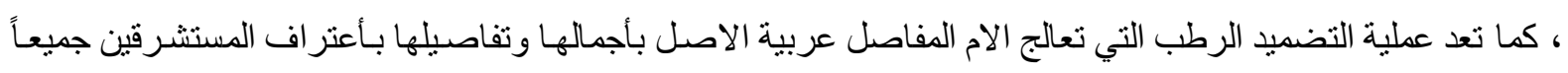

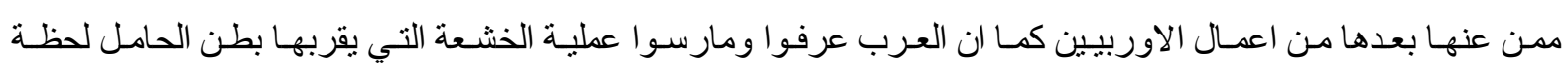

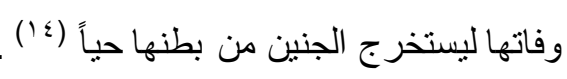


فضلاً عن كل ما تقدم كان للعرب قبل الاسـلام طب تجريبي حذقوه واتقتوه وكانت لهم معرفة واضحة بـالكثير من الامر اض وطرق العلاج و العمليات الجر احية التي كانت تجرى لاز الـة الجروح كمـا انهم ابدعو الفي عـلاج الكسور

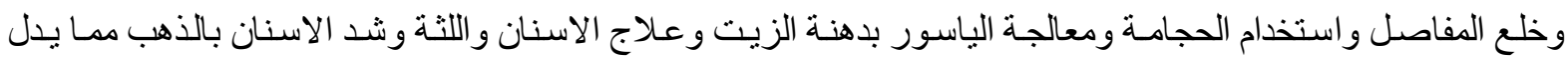
على بر اعتهم في فن التجميل ، كمـا ميزوا بين الامر اض المعدية وغير المعدية وكيفية اجتناب الامر اض المعديـة فيذكر

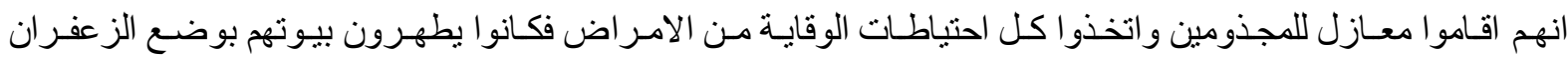

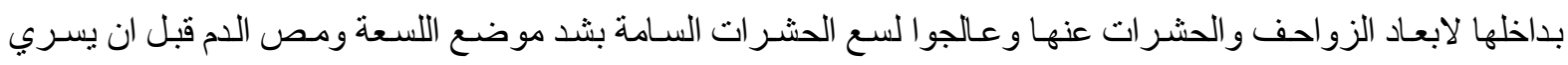

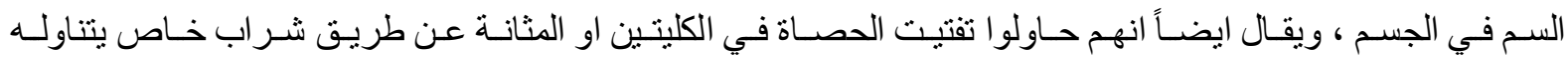

بعد ظهور الاسـلام ودعوته الى طلب العلم و الاخذ باسباب المعرفة لم يكتفِ المسلمون بالمعـارف السـابقة التي

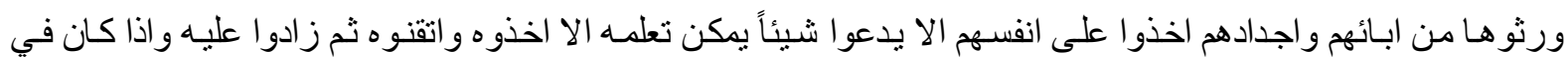

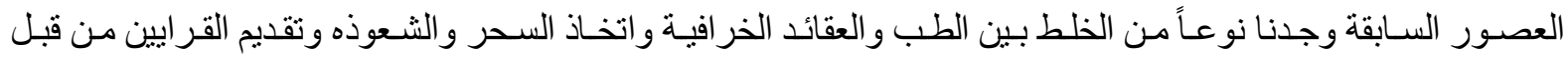

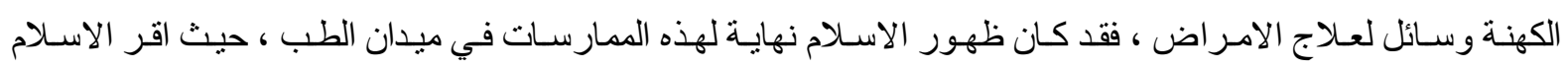

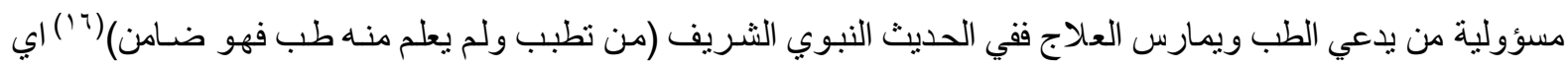

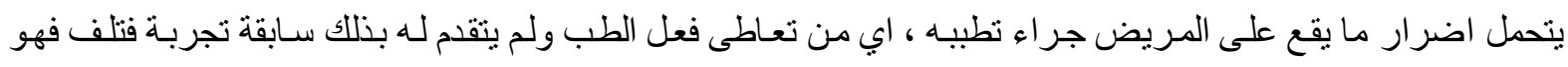

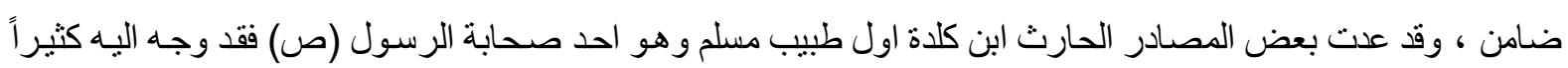
من المرض لعلاجهم ويذكر ابن قيم الجوزيـة انـه عندما مرض سـعد بـن ابي وقاص عـاده الرسول (ص) فوجده مقؤوداً

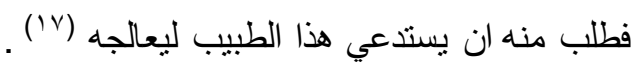
وقد روي عن النبي احاديث و افعـال تشـتمل عبى الطب و التطبيب بحكم تجربتـهـ كـان الرسـول (ص) ينصـح

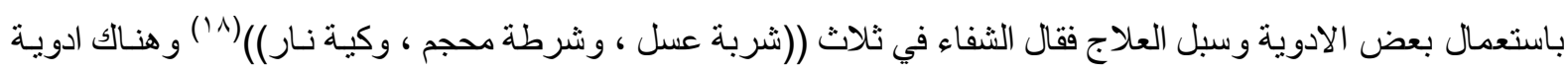

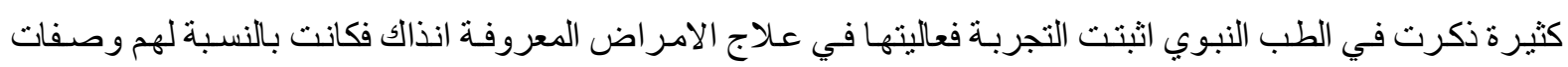
طبية وجدا فيها فائدة معروفة عن تجربة وهي ادوية مفردة في معظمها (9 (19) وفي العهد الاموي تقدم الطب كثير اً واشتهر عدد من الاطبـاء انذاك ومن اشهر هم ابن اثـال في دمشق وكسان

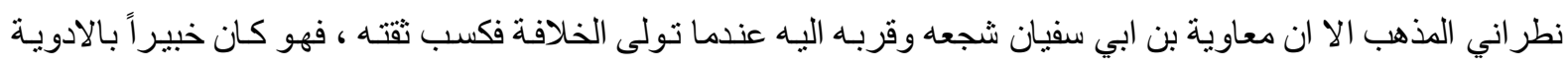

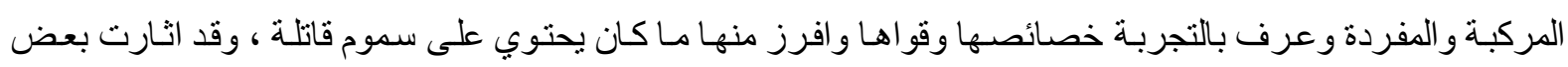

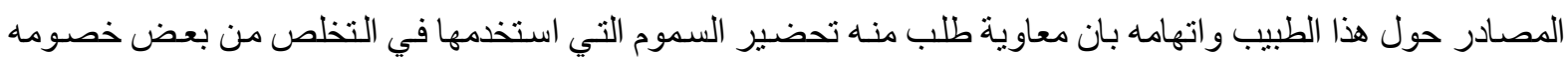

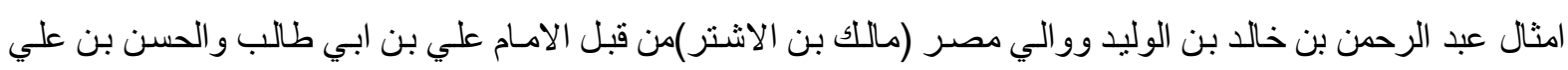

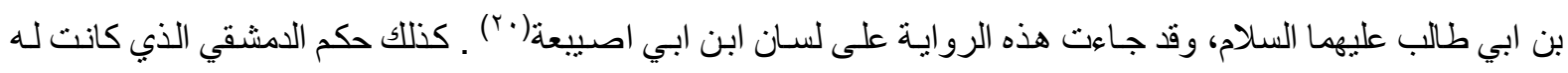

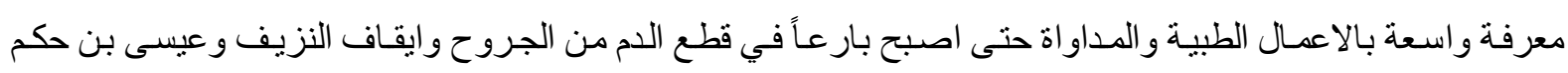
الدمشي الذي يمتلك خبرة كبيرة بالامر اض التي تصيب القولنج و استطاع علاج تللك الامر اض بقدرتهـ الفائقة على اختيار

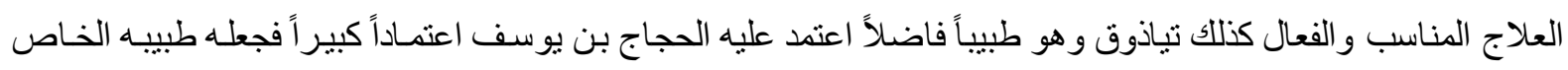

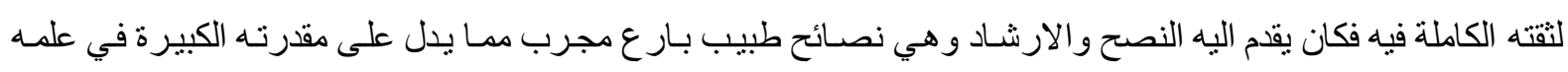

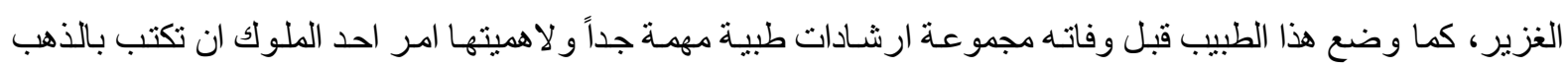

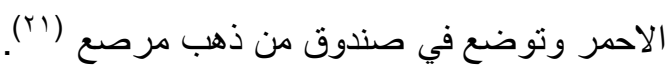


لقد كانت الجهود الطبيـة في العصـر الامسوي مقدمـة لحركـة النهضــة الطبيـة الثـاملة في العصـر العباسـي حيث

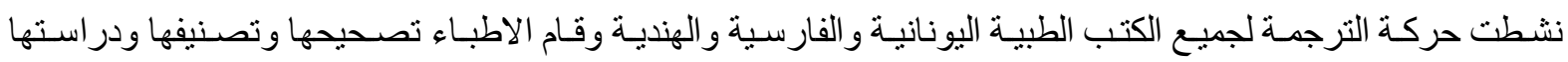
وجاءوا بابتكارات جديدة على ايدي الاطباء المسلمين الذين استفات منها اوربا فيما بعد في هذ المجال .

بعد قيام الدولة العباسية اصبحت بغداد عاصمة العالم في العلوم كلها من سياسية و اقتصـادية وكيميائية وطبية ،

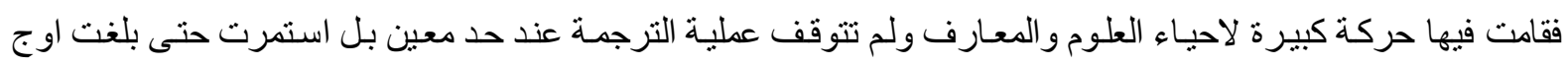
عظمتها في منتصف القرن الرابع الهجري واصبحت اساسـاً متيناً لحركة التأليف الواسعة المبنية على الاضسافة الاصيلة خاصة في علم الطب والتي تعبر عن نطور أ كبير اً لهذه المهنة على يد اطباء العرب وبلغت حركة التأليف هذه ذروتها

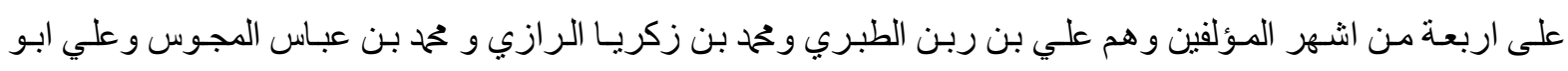

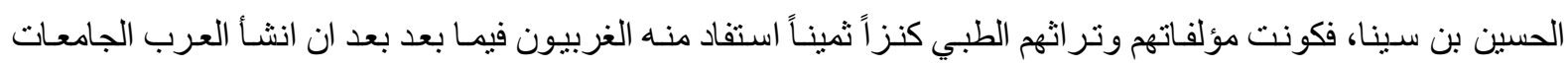

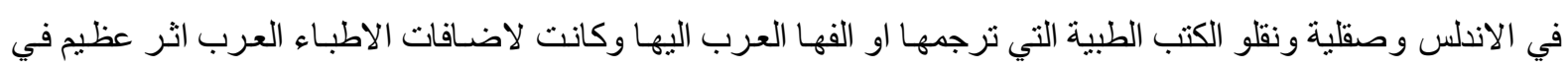
قيام النهضة العلمية في اوربا واصبحت من اهم دعائم الحضارة العربية الاسلامية (rr) . ولمـا كـان عنوان البحث محدد باهميـة التجربـة في طب فلاسفة الاسـلام لذا سنقف عند محمد بن زكريـا الرازي

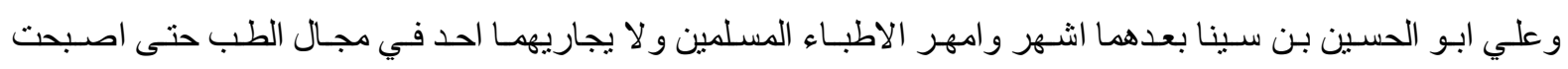
ممارسة الطب على ايديهم وتعليمـه جز ءاً لا ينفصل عن بقيـة الاختصاصـات وخاصـة الفلسفة وكان لإضـافاتهما التجريبية و التطبيقية في مجال العلوم الطبية اكبر الاثر على الطب من خـلال فحص المريض والتطبيق العملي عليه في في المستشفيات واختيار العلاج المناسب من خلال نلك كله (rr).

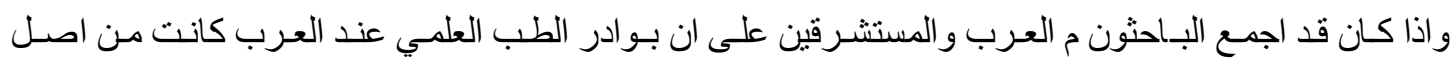
يونـاني وفضل اليونـانيين على هذه الصناعة هو انهم وضعو الفنونها القو اعد الاولى التي كانت في اغلبها نظريـة فـانهم

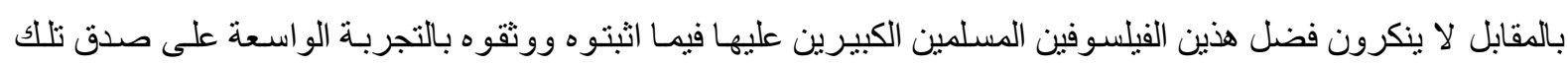

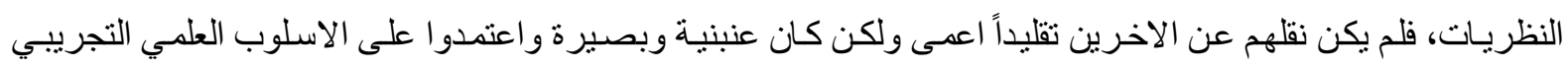

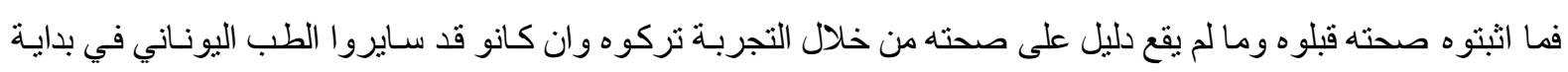

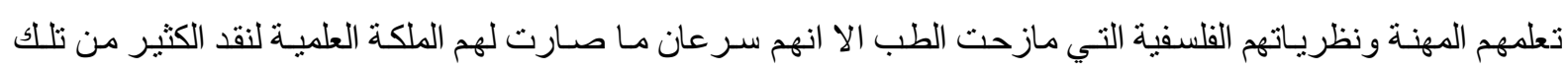

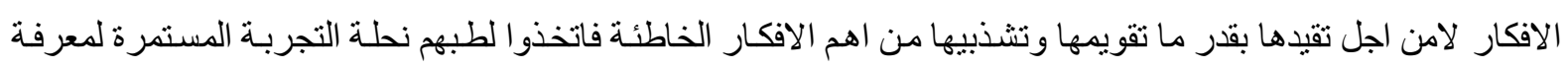

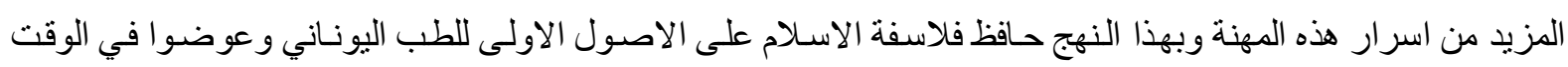

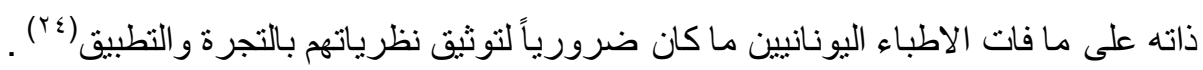
عند دراسـة التراث الطبي عند الفيلسوفين الرازي وابن سينا نجد انها يمثّلان اتجـاهين اساسين فيه ، الاول هو الاطباء الفلاسفة ويمثلهم الرزاي والثاني هو الفلاسفة الاطباء ويمثلهم ابن سينا هذان المذهبان احدهما يكمل الاخر فالاول

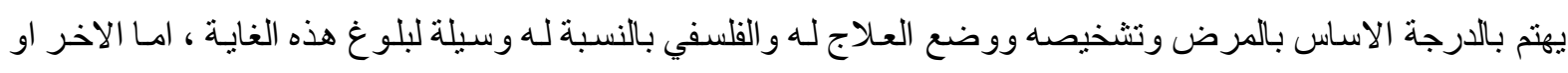

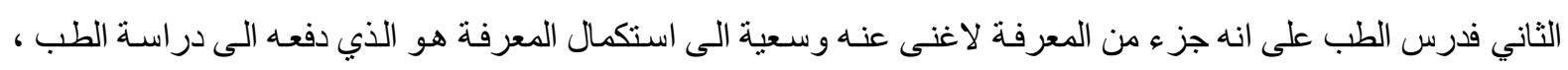

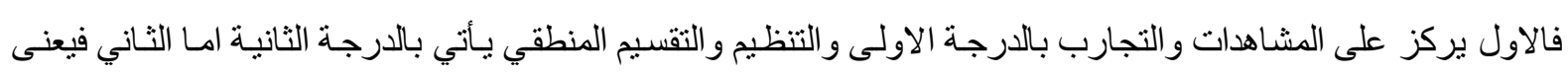

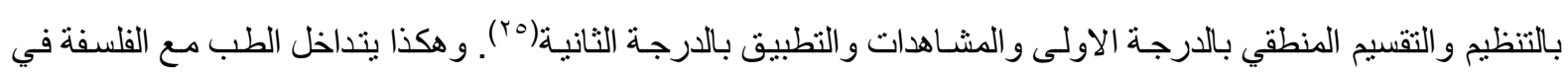
تراث هذين الفيلسوفين وان كـان هذا التداخل بين الاثنين لبس بجديد في الفكر الفلسفي الاسـلامي وانمـا بدأ عند اليونسان 
و استمر كذلك عند فلاسفة الاسلام وخاصة الاطباء منهم ، لذا نجد عندهم اثر الفلسفة على الطب واضحاً لبس في الجزء

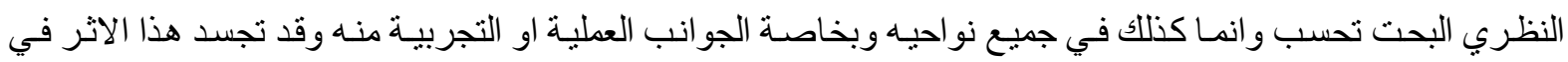
فكر الفيلسوف الطبيب ابي بكر الرازي اكثر من غيره .

فلسفة الطب عند الرازي تبدأ باكتشاف العلة اولاً ثم السعي لاز التها ولهذا الابد ان تبدأ هذه الفلسفة بوضع حدود دقيقة لما يسمى بالفلسفة بالتعارف او الحدود فجعل ابو بكر الرازي مبحث التعريفات في الطب مستنداً على مبحث العلل،

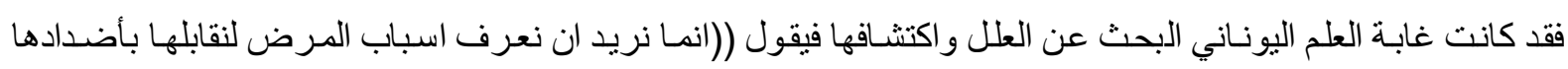

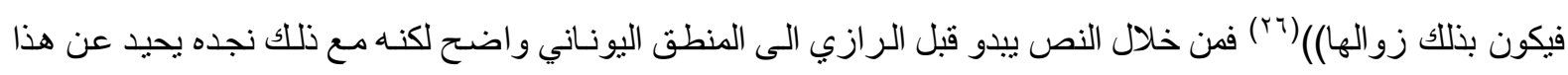

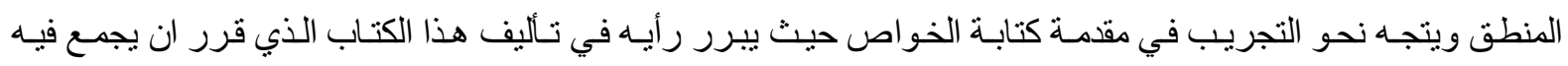
اقوال الناس في خواص الاشياء ويحذر من قبول هذه الخواص دون التثبت منها بالتجربة (rv) . وتاكيداً لميل الرازي نحو التجريب في طبه جاء احد مؤلفاته يحمل هذا العنوان وهو كتاب التجارب الذي يحوي

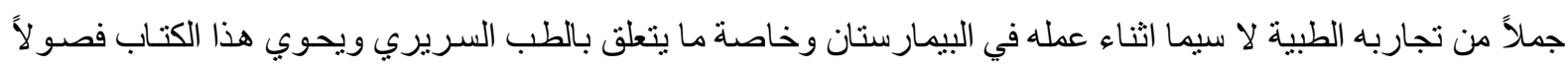

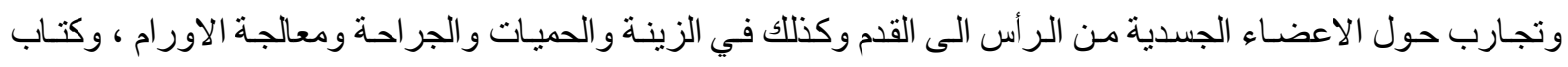

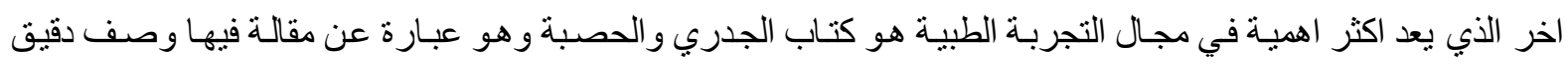

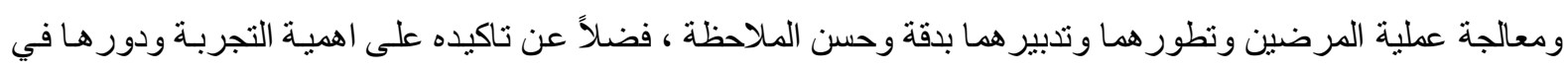

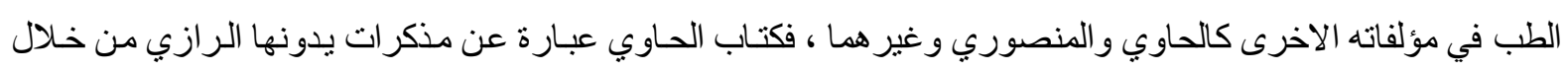

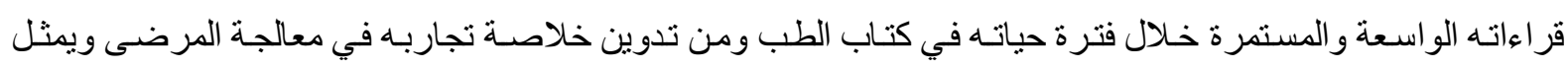

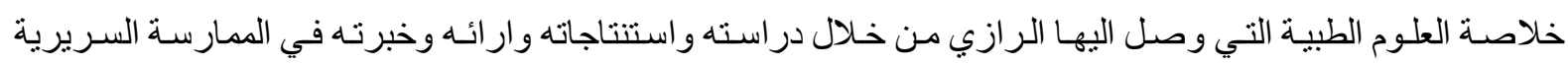

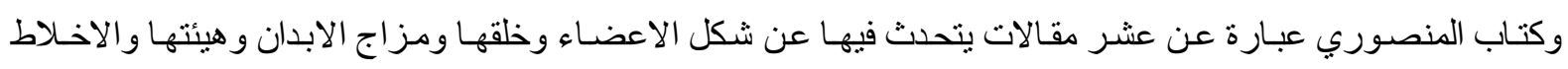

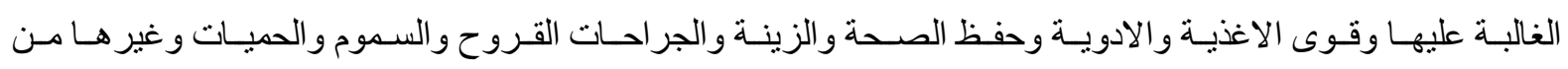

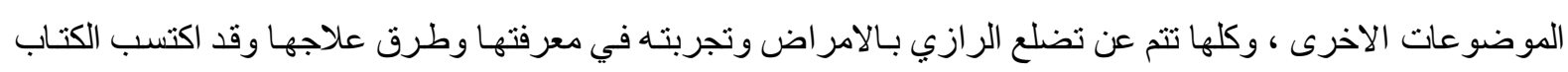

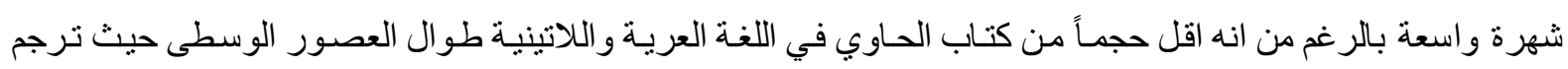

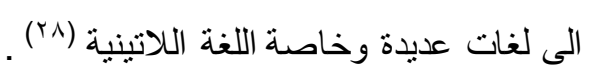

التجربـة عند الرازي هي الحد الفاصل بين الحق و الباطل فكثير من الجواهر الاشياء لها افعـال عجيبة ربمـا لا

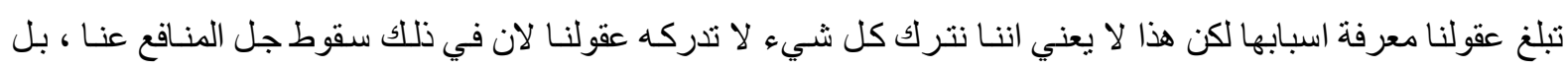

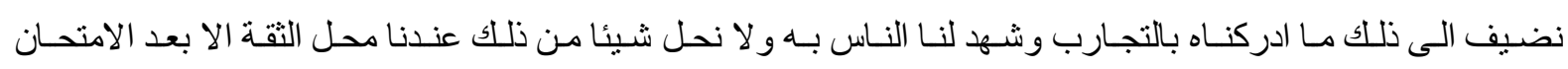
والتجربة له، اذن لم يكن عندنا شيء نختبر به حق المحق وباطل المبطل في هذه الاشياء الا التجربة .

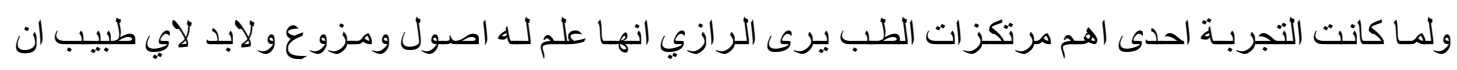

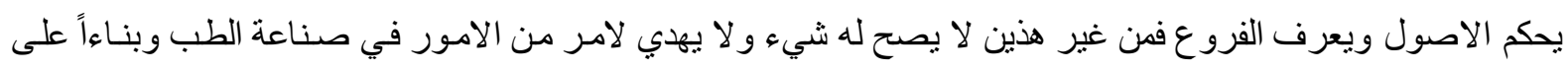

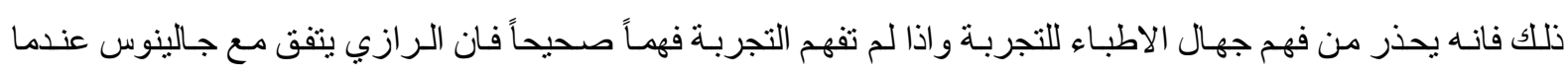

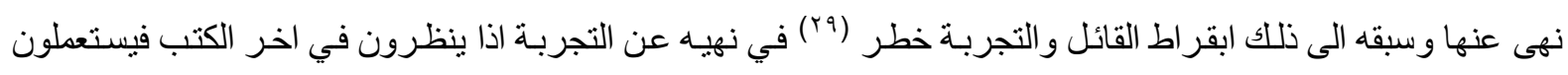
العلاجات وليس يعملون ان الاشياء الموجودة فيها ليست هي اشياء تستعمل بأعيانها بل هي مثالات جعلت لتحتذبي عليها

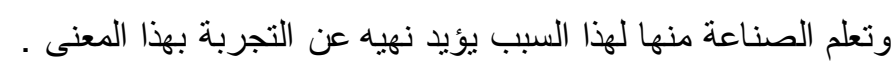


اهم مـا يميز تجربـة الر ازي في الطب انهـا تجربـة موجهـة ولم تكن اتفاقيـة كتلك التي وجدناها عند الاطبـاء اليونـان، ولكي يتحقق الرازي مثثلً من اثر القصد كعـلاج لمرض الرسـام وهو مرض في حجب الدماغ او الر أس قسم مرضاه الى مجمو عتين يعالج احدهما بالفصد ويمتنع عن فصل الاخرى ، ثُم ير اقب الاثر و النتيجة عند افر اد المجموعتين حتى ينتهي حكم في قيمة العـلاج فيقول في حديثه عن حالة تتذر بمرض السرسام (فمتى رايت هذه العلامـات تتقدم في

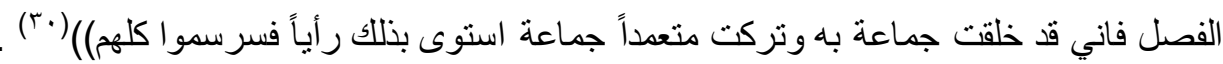
و لا در اكك الر ازي اهيـة التجربـة فقد قام بنفسـهـ بـاجر اء بعض التجـارب على الحيوان وخصوصـاً على القردة بعدها اقرب شبهاً بالانسان و لا يز ال الطب الحديث يقوم بـاجر اء التجارب على الحيو انـات قبل اجر ائها على الانسان فقام

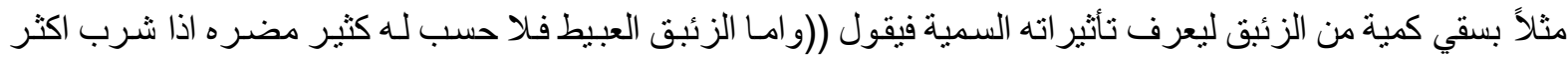

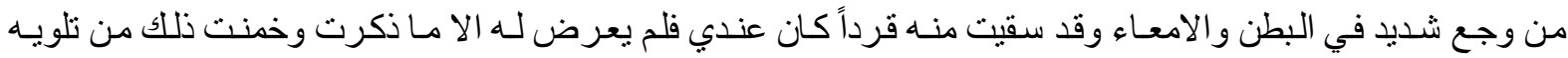
وقبضه بفمه ويديه على بطنه ، ولعل هذه التجربـة قادت الرازي الى استعمال الزئبق شر اباً لمعالجة انسداد الامعـاء ، فهو

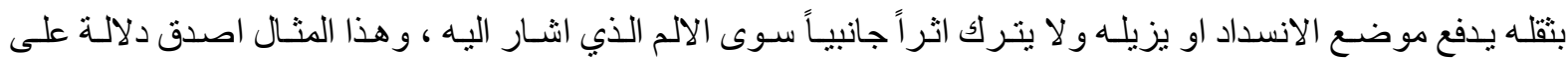

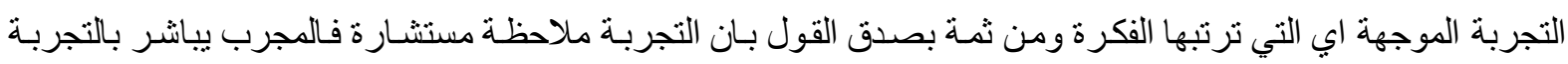

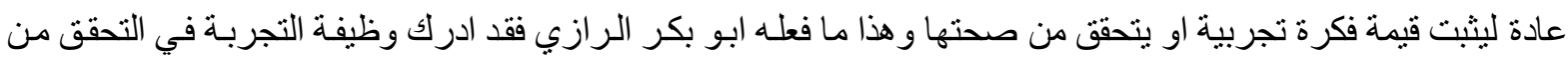

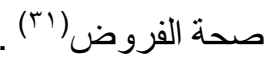
كما جرب الر ازي الجبسين و النور و ههـا من مكونـات الكالسيوم فوجد لـه القوة راسخة لازقة وذلك ان يتحجر

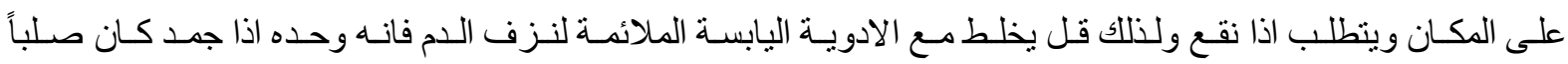

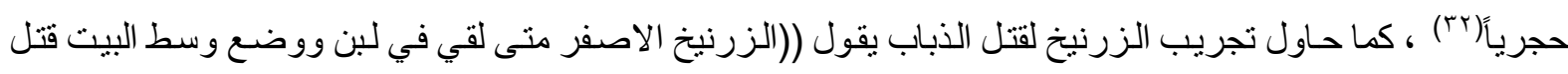

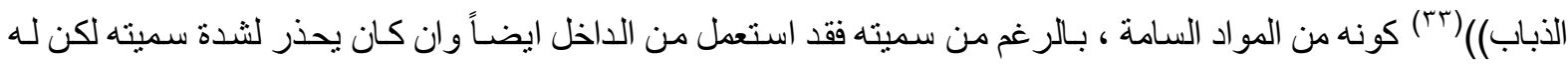

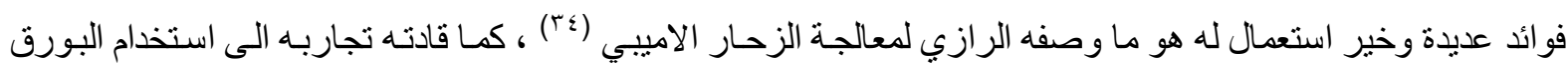

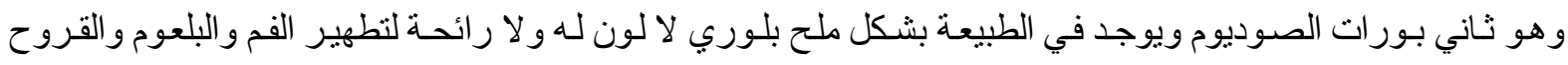

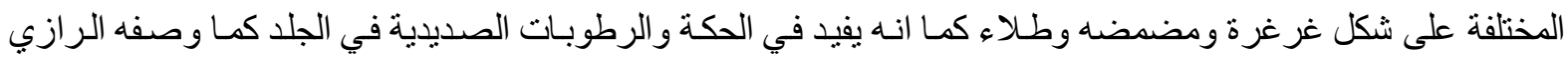

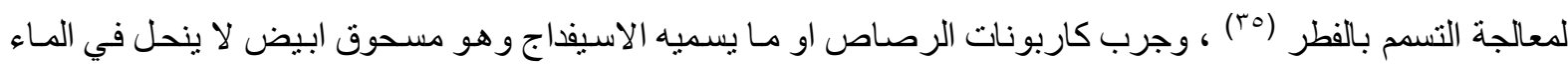

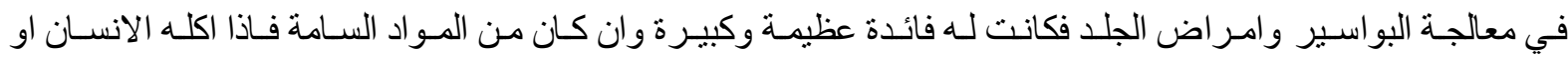

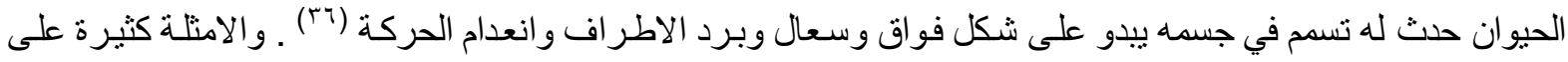
تجارب ابي بكر الر ازي لا يسع المكان لذكرها جميعاً لانها تحتاج الى مؤلف كامل لاحصائها وذكر ها في مكان واحد . . لهان. لقد كـان الرازي ميـالاً الـى التجربـة لانـه يـرى ان الثـكوك المغلوطـة تقع في الاكثر في الفن النظري مـن الفن

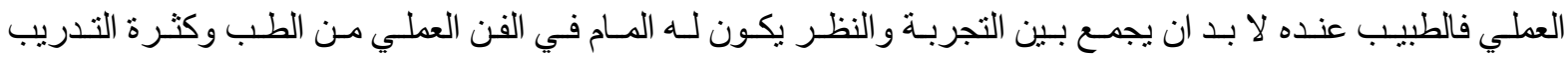
و التجربة فان اختلفا فيه فليعرض على كثير من اصحاب التجارب فاختيار الرجل المجرب اكثر نفعاً في صناعة الطب

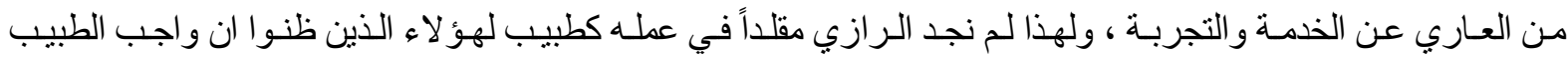

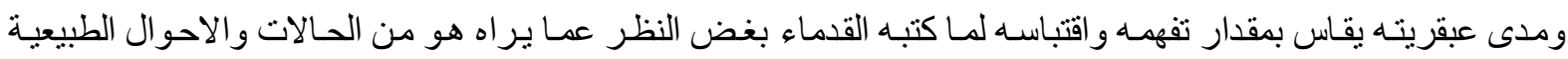

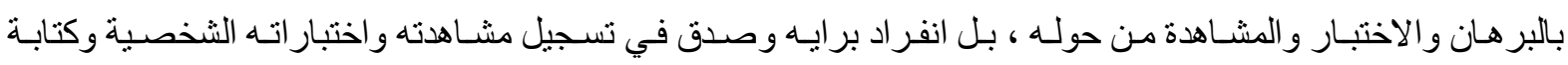

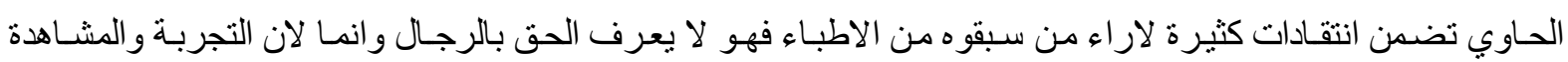


سبق وان اشرت الى ابن سينا مثل اتجـاه الفلاسفة الاطبـاء في الفكر الفلسفي الاسـلامي ، وهو اتجـاه يؤكد حاجة

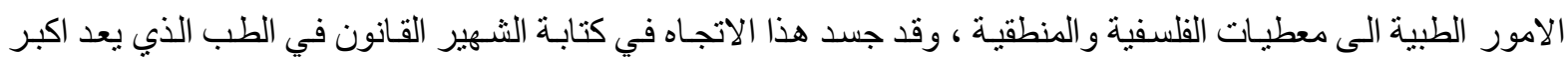

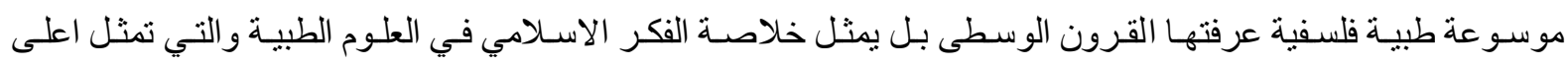

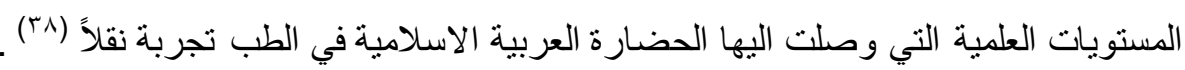
القـانون في الطب بمثل بـلا شـك دستوراً ابن سينا الطبي الذي تحسث فيـه عن الامور الكليـة اولاً ثم الامـور

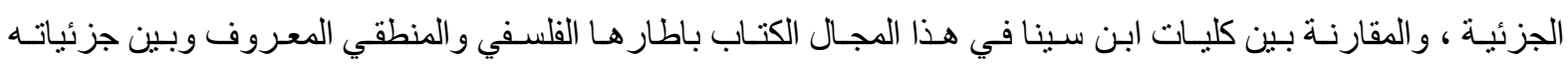

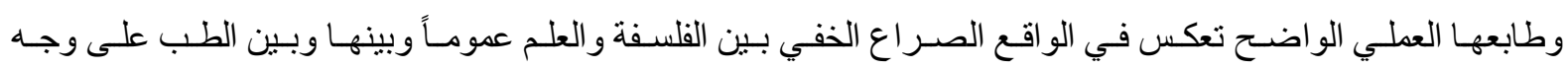

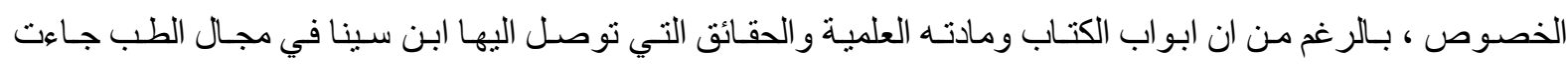

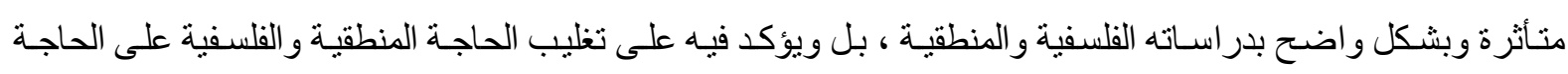

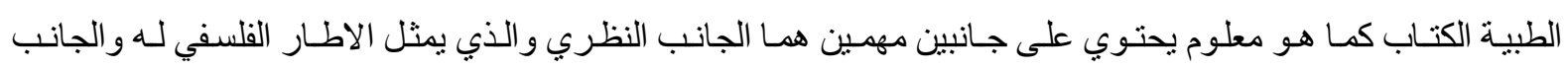

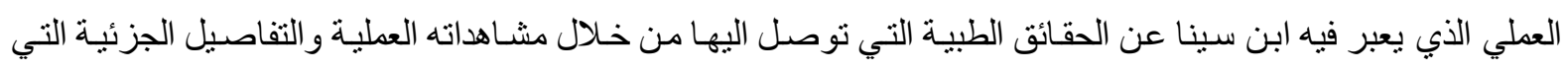

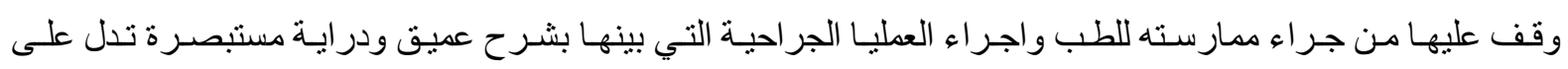

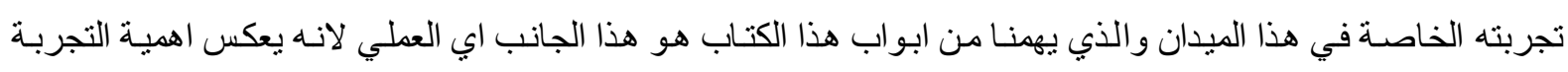

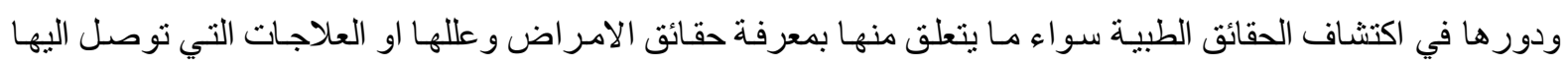

للشفاء منها . ودوري

اعتمد ابن سينا في تشخيصـه للامـر اض على جمـع الاعر اض و هي غالبـاً مـا تكون موقته تبتدئ وتنقطع من

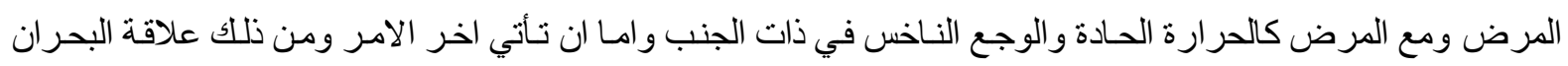

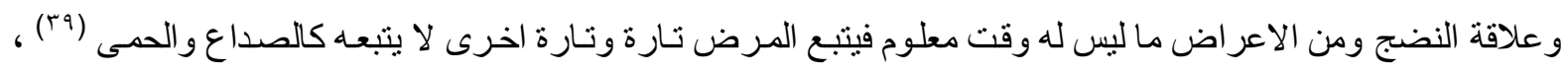

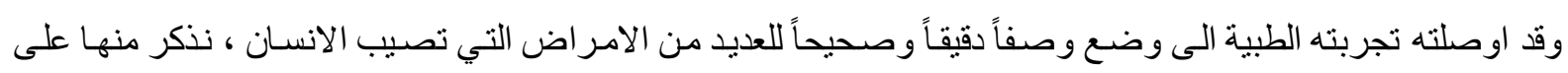

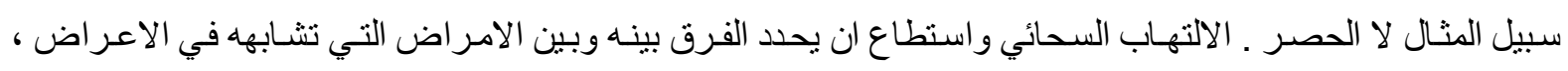

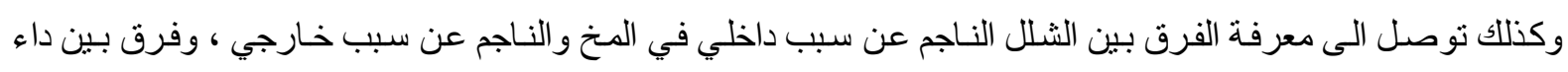

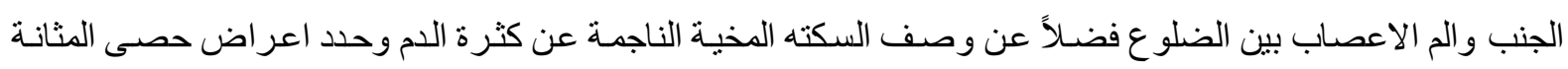

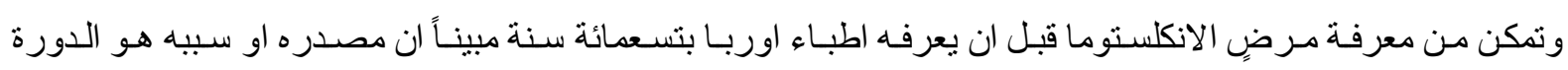

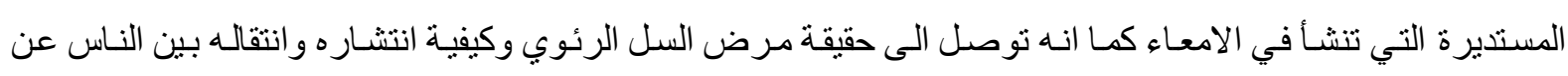
طريق المـاء و التراب ووصـف العديد من الامـراض الجلديـة والتناسلية والاضطر ابات العصبية وعرف امر اض العيون و الامر اض التي تنتقل الى الانسان بواسطة مياه الشرب وارجع سببها الى حيو انـات دقيقة موجودة في المساء لا ترى بـالعين

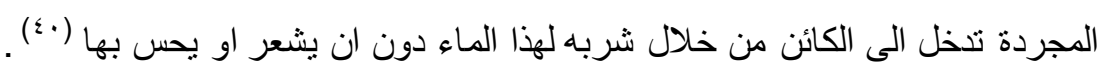

كما يعرض ابن سينا بحثه التجريبي عندما يبدأ الحديث في الطب عن تثريح العضو ثم يعقب ذلك بيـان كيفية

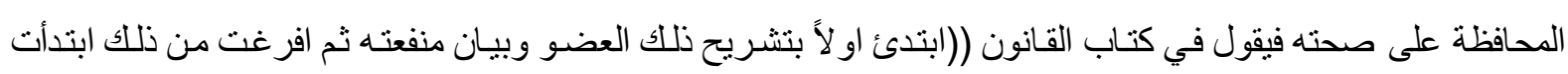

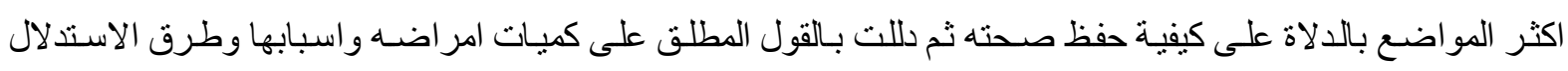

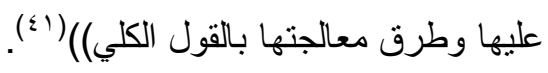


المتتبع لخطوات معالجة الامر اض عند ابن سينا سيكتشف بوضوح مـا احتوت عليه هذه المعالجات من منهج تجريبي فقد جعل لها قو انين ثلاثة هي اختيار كيفية من حيث الحرارة و الرطوبـة واليبو سـة والبرودة واختيـار كمية ومقدار

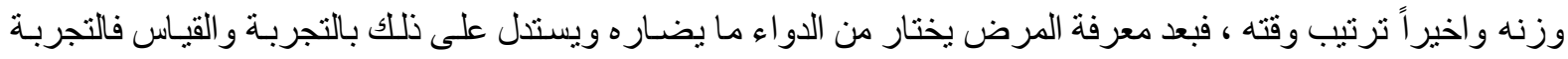
ترينـا ان الحر ارة تبرد بـالبرودة والعكس صحيح و القياس مفيد في الامـر اض المتشــابهة في الاعر اض ثم يفرق بينها

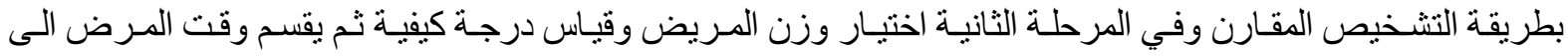
مرحلة الابتداء و التزيد و المنتهي والانحطساط ، على ان يرعى في ذلك الاوقـات و المعالجـات ، مؤكداً على عدم الوقوف

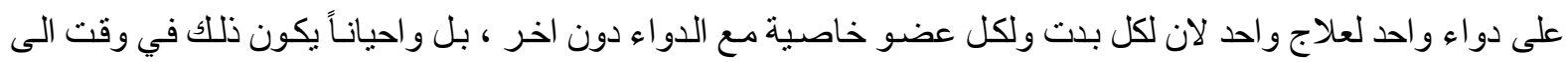

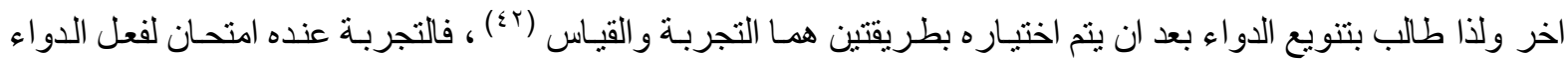

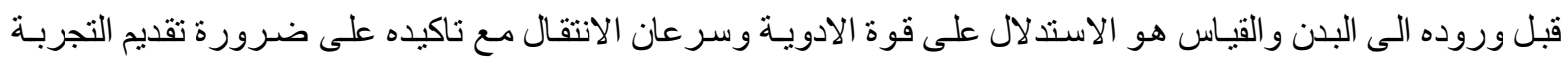

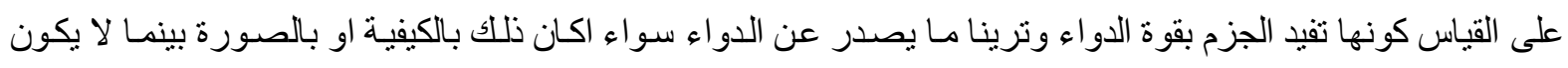

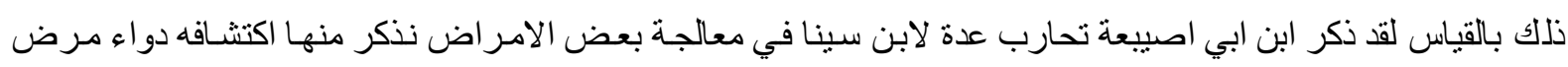

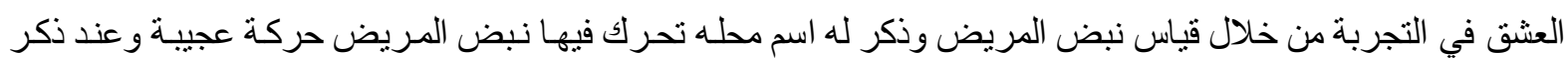
اسم معين بالذات تحدث الحركة ذاتها في نبض المريض ، كذللك معالجته لمرض الصداع بو اسطة استخدام الثلج وقد ذكر

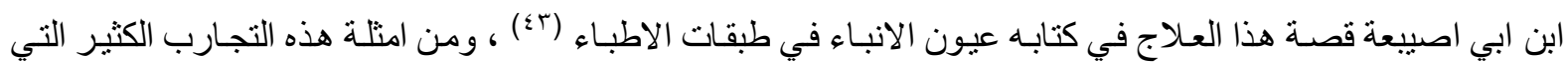

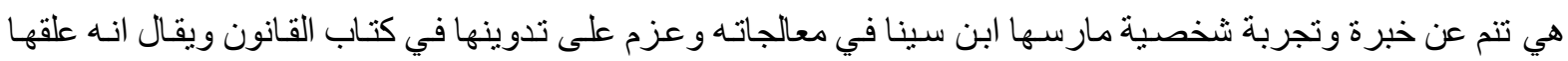
على اجز اء فضاعت قبل اتمام الكتاب وقد وصفها ابن سينا بنفسه بـان انفتح عليه من ابو اب المعالجـات من التجربـة مـا لا يوصف (๕)

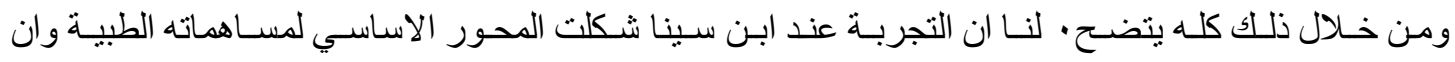

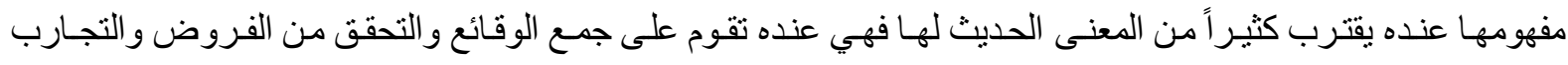

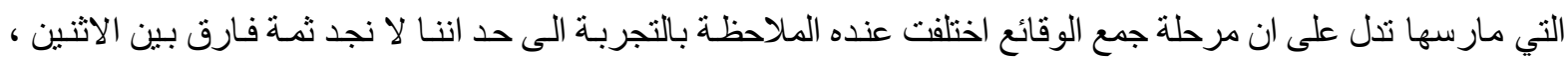

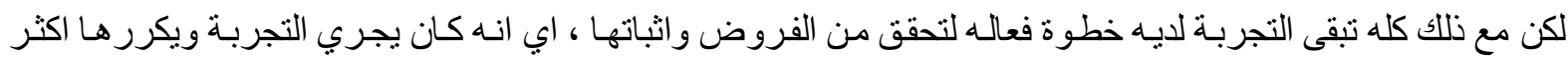
من مرة فان ظهرت له الاعراض ذاتها في الظـاهرة توصل الى تشخيص علتها ومعرفة سبيها ، فدر اسـة الظـاهرة العلمية عنده لا تقف عند حدود الوصف و التعريف او التعليل الميتافيزيقي او الغائي ، بل تقوم على مشـاهدة الاعر اض واض والدلالات

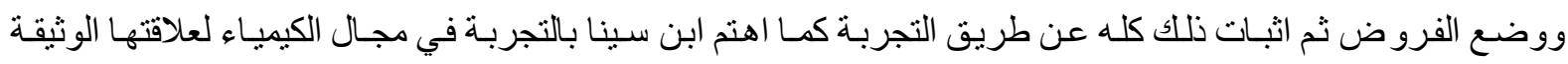

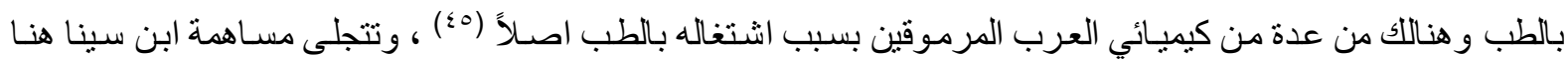
من خلال صناعة الادوية الطبية فقد وضع شروط عدة لمعرفة قوة الادويـة وهذه الشروط اتخذت من التجربـة اساسـاً لها وعد هذه الشروط دستور اً للاختبار العلمي نذكر من هذه الثروط ان يكون هذا الدواء خالياً من كيفية مكتسبة وان يكون المجرب عليه مفردة وان يكون الدواء قد جرب على العلل المضـادة وان يكون قوة الدواء مسـاوية لقوة العلة مـع مر اعـاة

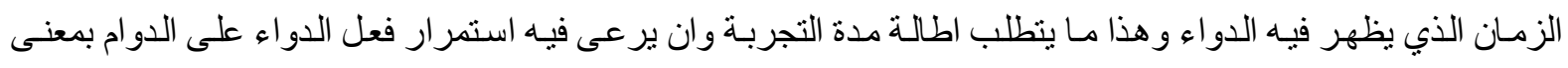

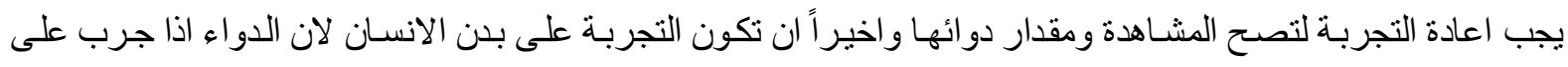

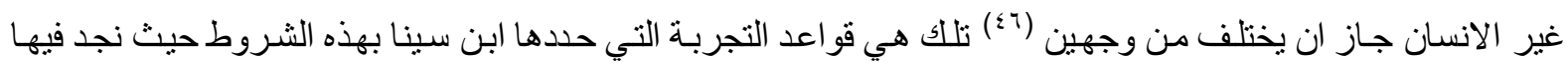

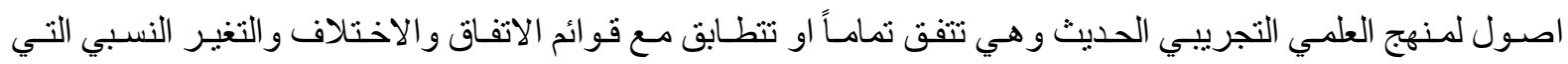

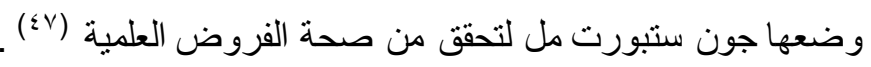




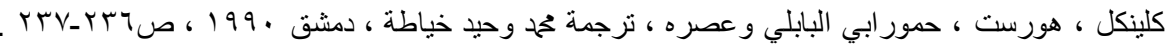

الشطي ، احمد شوكت ، موجز تاريخ الطب عند العرب ، دمشق ، 1990 ، صلامب .

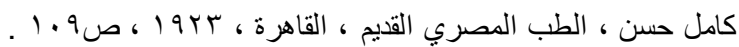

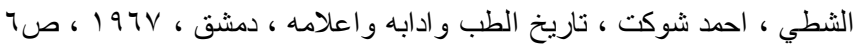

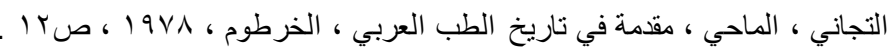

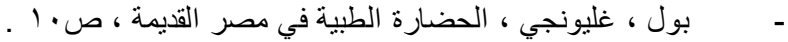

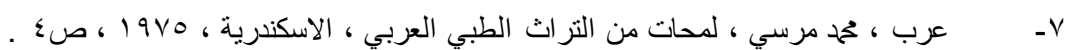

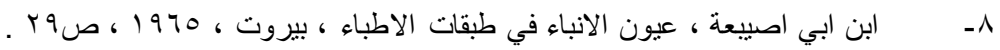

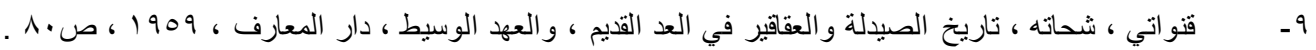

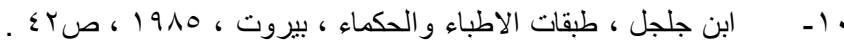

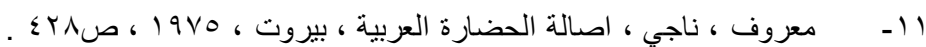

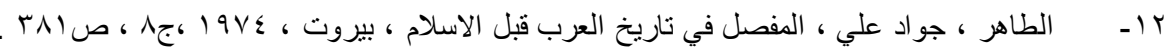

rا

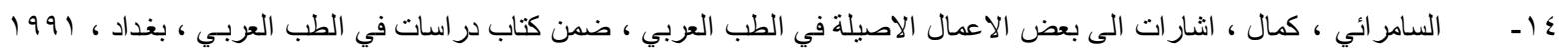

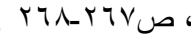

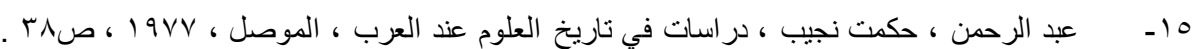

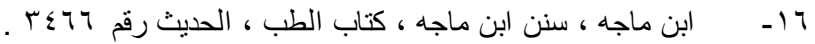

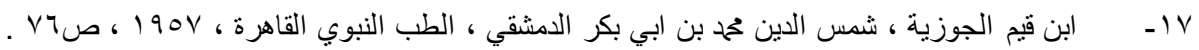

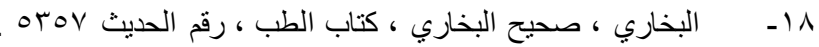

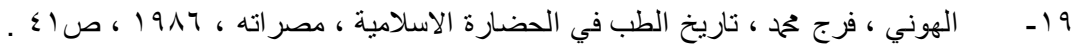

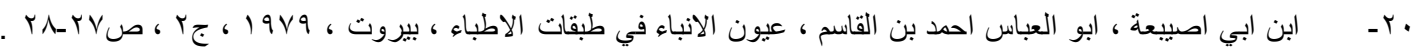

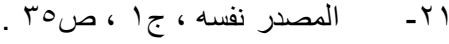

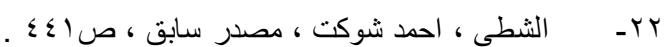

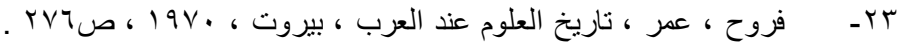

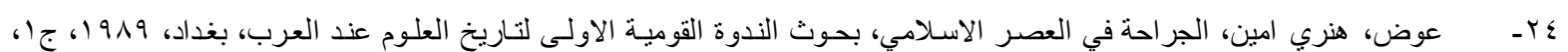

ص מ

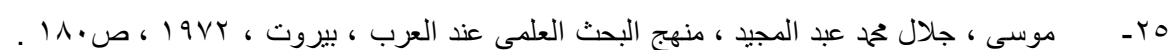

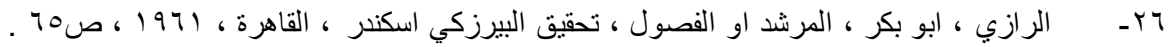

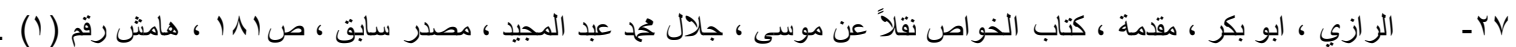

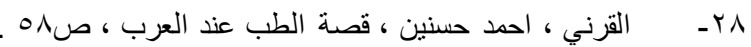

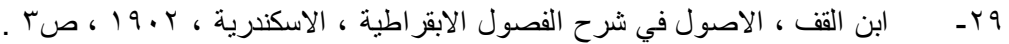

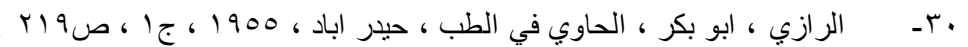

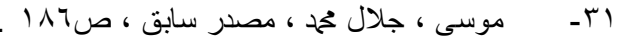

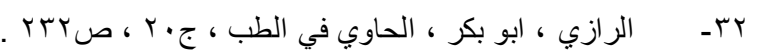

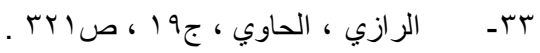

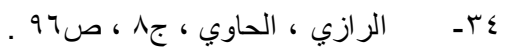

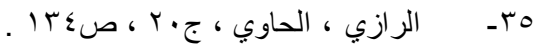

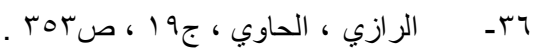

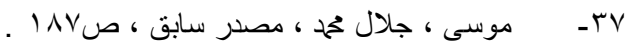




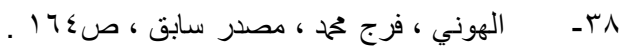

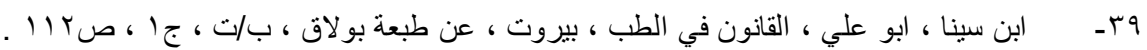

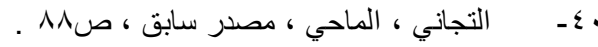

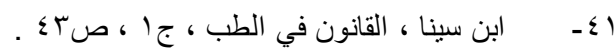

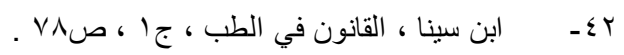

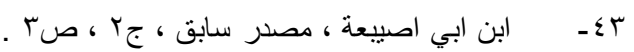

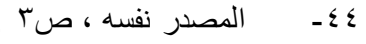

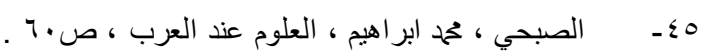

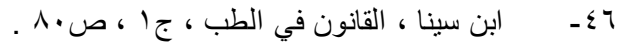

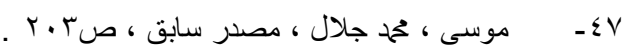

\section{همادر البمث}

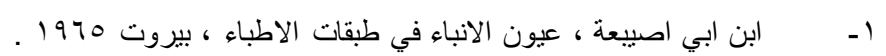

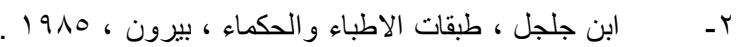

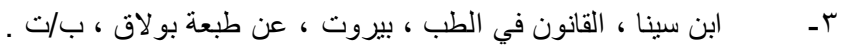

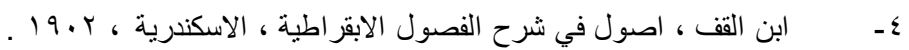

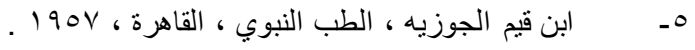

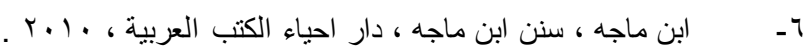

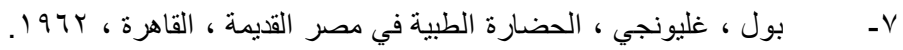

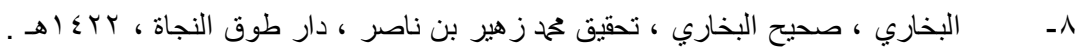

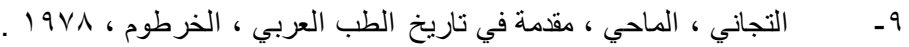

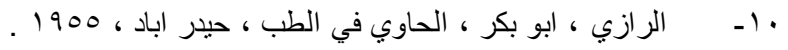

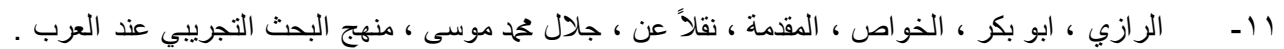

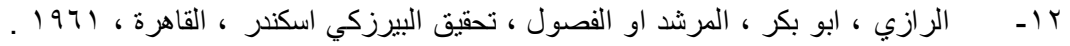

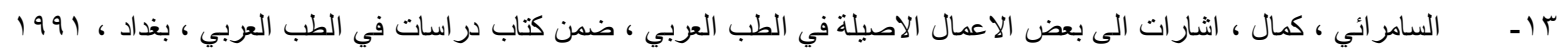

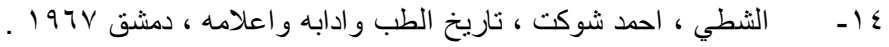

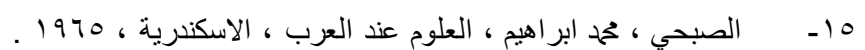

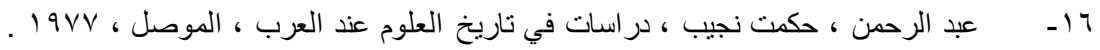

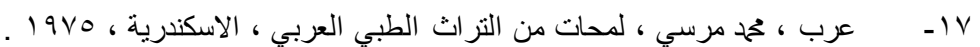

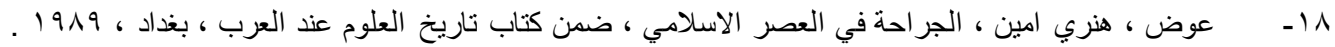

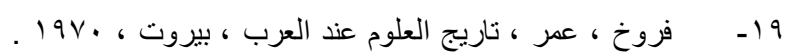

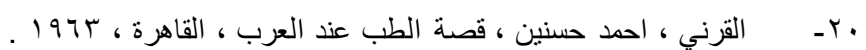

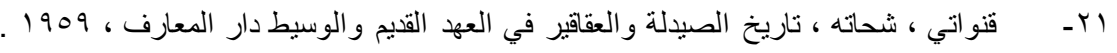

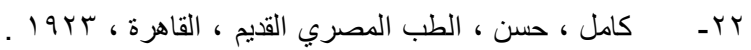

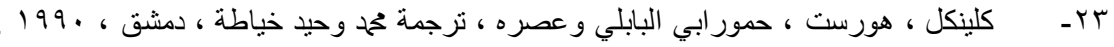

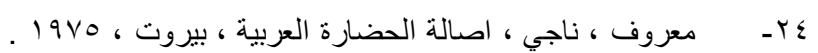

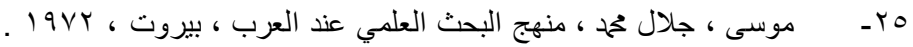

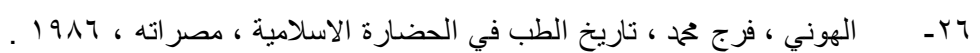

